\title{
Autonomia in the 1970s \\ The Refusal of Work, the Party and Power
}

\section{PATRICK CUNINGHAME}

UNIVERSIDAD AUTÓNOMA CIUDAD JUÁREZ

Autonomy is the ability to give an adequate rule to desire, and not the art of begrudging the world.

Franco Berardi (Bifo) ${ }^{1}$

Not only is it freedom, but an anthropological growth that causes an accumulation of desires, of necessities, of will; it is, principally, a collective phenomenon, it is deeply cooperative. Autonomy is of the common.

Antonio Negri ${ }^{2}$

\section{-INTRODUCTION}

The Italian new social movement of the 1970s, Autonomia (Autonomy), was a key collective actor in late twentieth-century Italian protest and social conflict. It played a significant role in the conflictual and relatively rapid transformation of Italy from a recently industrialised nation to a post-Fordist, post-industrial society. The experience of Autonomia has highlighted the changing nature of collective identity, political organisation and social contestation in advanced, urbanised 
capitalist societies. It represents, furthermore, a still unfinished chapter in recent Italian history due to the failure of the political class to reach a political solution on the fate of the remaining political prisoners and exiles from the 'Years of Lead'. The emergency legislation of the 1970s continues to undermine the democratic fabric of both state and society. The lack of a satisfactory solution for all sides of the virtual civil war that existed in Italy in the late 1970s has fostered silences, omissions and distortions in Italian intellectual and academic life on a crucial period, helping to leave unsolved and unpunished the 'Strategy of Tension' bombings of 1969-84, allegedly committed by the state itself. So one of my aims is to unpack the myths and conspiracy theories surrounding Autonomia and the 1970s to clarify better its role as a movement involved in the conflicts of a period of almost continuous political and economic upheaval and of profound cultural and social change.

With reference to the debates surrounding the origins and nature of social movements, it is surmised that the 'cultural' version of new social movement theory (Alain Touraine and Alberto Melucci) overemphasises the cultural aspects of new social movements, while minimising their primarily political goals, forms of organisation and impact on the state and civil society. The 'political' version (Manuel Castells and Jürgen Habermas) ignores the cultural impact of new social movements at the symbolic level, considering them as 'partial' phenomena, unable to effect the state unless in alliance with the parties and trade unions of the historical left. Both versions tend to ignore the historical links between 'old' and 'new' social movements in order to emphasise the 'newness' of the latter. Classical Marxism has tended to treat social movements as potentially reactionary and in any case marginal to the central labour-capital conflict, while neo-Marxism, in its structuralist and Gramscian versions (Ernesto Laclau and Chantal Mouffe, David Plotke), has similar limitations to those of 'political' new social movement theory: these movements are politically significant only when in alliance with officially organised labour. Ultimately, all of these perspectives tend to undermine the political significance of new social movements since the 1960s when compared to institutional politics. Moreover, the centrality of the issue of 'newness' in the debate between new social movement theory and Marxism seems to be a divergence compared to other more important aspects. I argue that the academically imposed division between culturally oriented new social movements and political 'class struggle' is false, as is the attempt to divide these movements into 'bad' residual/violent/political and 'good' emergent/nonviolent/cultural elements.

Autonomist Marxism has attempted to bridge this gulf, although it can be criticised for attempting to conflate contradictory phenomena such as feminism and youth counter-culture with class politics, and, in the case of the Italian workerism (operaismo) from which it springs, for failing to go beyond the 'workers' centrality' focus of classical Marxism. Despite these limitations, however, it represents a form of political and sociological analysis that has emerged from within the Italian new social movements themselves and is therefore directly related to their social 
composition and forms of organisation and mobilisation. It emphasises the autonomy of the working class from capital, that is of 'living labour' from 'dead labour'. ${ }^{3}$ It valorises difference and identifies as central to the class struggle those sectors seen by classical Marxism, neo-Marxism and 'political' new social movement theory as 'marginals': homemakers, students, youth, 'precarious' workers, the unemployed and 'Third World' peasants, that is, those who tend to organise 'spontaneously' and autonomously from the structures of the official left, often as movements. Finally, it uses oral history and sociological research through the revival of Marx's 'workers' enquiry' to generate hypotheses from the raw material of everyday grassroots struggle, rather than 'top-down' macro-analysis.

Autonomia reached its peak as an incisive socio-political force during the upsurge in protest and conflict during 1977, but rapidly disintegrated following the waves of arrests of thousands of militants between 1979 and 1983, accused of forming 'armed gangs' to subvert the state. According to one ex-political prisoner, over ninety per cent of those arrested chose to testify against their former comrades as 'repentant' or 'disassociated' witnesses. ${ }^{4}$ After this period of criminalisation, during which some 15,000 militants were preventively incarcerated in 'special prisons' for extensive periods before standing trial, the remnants of Autonomia revived in the mid 1980s as the 'antagonist movement'.5 Some two hundred activists from the 1970s still live in juridical limbo as unofficial refugees in Paris with little prospect of an amnesty. ${ }^{6}$ Nevertheless, given the continuing activity of mainly counter-cultural youth social movements in Italy, particularly the 'centri sociali' (squatted social centres), ${ }^{7}$ and despite (or because of?) the disappearance of the New Left organisations of the 1970s, how can the continuing resonance of Autonomia in contemporary Italian society be explained?

One of the central characteristics of the new social movements, separating them from the spheres of institutional or 'revolutionary' party politics, or indeed from other forms of collective action such as interest groups and protest campaigns, is that of 'autonomy'. In the collective sense, it signifies the need of different groups of actors to protect and advance their own agendas without being subsumed by the demands of a wider collectivity, whether civil society, the working class or other social movements. Although the emphasis was on the collective, autonomy was also seen as an individual demand and practice: the diversity of the needs of the individual could not be subordinated to the voluntarism of party discipline. This autonomy of the individual within the immediate collectivity of a social movement and the broader collectivity of civil society found its apposite political expression in the direct, participative democracy of the assembly and the refusal of delegation or of any form of representative, institutionalised democracy.

The first problem, however, is one of description: which Autonomia are we dealing with? The Workers' Autonomy of the self-organised factory assemblies of Porto Marghera, Milan, Turin and Rome, of 'workers' autonomy' against work and capitalist command as expressed through the factory system and its wage differentials? The Organized Workers' Autonomy of Antonio Negri, 
Oreste Scalzone and Franco Piperno, 8 the 'Padovani' and the 'Volsci', 9 who attempted to build a new kind of revolutionary 'vanguard party'? The 'armed Autonomia' of those, disillusioned and frustrated by the political containment and defeat of the 1977 Movement, who established the many tiny and often short-lived groups of the terrorist 'second wave'? The 'creative Autonomia' of the 'metropolitan Indians' and the 'transversalists' of Radio Alice and the network of 'free radio stations', street theatre collectives and small publishers? Or the 'diffused area' of Autonomia, which not only encompassed all these realities, including secondary school occupations, women's groups and neighbourhood committees, but was also in deep contradiction with the more 'organised', neo-Leninist part of the movement?

-WORKERS' AUTONOMY AND THE REFUSAL OF WORK

You learnt how to read a wage slip, how to see wage differentials, to see what were the work processes. How, also, to understand the work processes in a chemicals factory, which is not easy compared to manufacturing factories. What were the points, for example, of possible sabotage or that could be blocked with a strike?

Alisa Del Re ${ }^{10}$

The historical core of Autonomia, namely the theory and practice of workers' autonomy and the refusal of work, lasted from the early 1960s to the great defeats of the early 1980s. The development of the autonomous workers movement was closely related to the evolution of Italian workerism, its emergence having been researched in their journals, Quaderni Rossi and Classe Operaia in the early 1960s, before it became an identifiable collective phenomenon during the 'Hot Autumn' wildcat strike-wave of 1969. However, the autonomous workers movement's main organism, the Autonomous Workers Assemblies, had an often conflictual relationship with the Factory Councils, ${ }^{11}$ one of the main gains from the Hot Autumn as formally constituted in the 1970 Workers' Charter.

The autonomous workers saw themselves as a 'resistance movement' against industrial and technological restructuring and its political basis, the 'Historical Compromise' between the PCI and the Christian Democrats. Various forms of the refusal of work, wildcat strikes and industrial sabotage were the 'weapons' in this struggle. The highpoint was what Negri termed the 'Workers Party of Mirafiori', the strike and occupation of the giant FIAT plant in Turin by the 'Red Bandannas', the most militant autonomous workers, in March 1973.12 Also important was the relationship with non-industrial workers, particularly in the growing service sector and the radicalised sections of the professions, as well as with unpaid labour, like the 'house workers' of the 'workerist' section of the women's movement, the movements of the unemployed in the south, and the university and school students' movements. 
As the autonomous movement of the 'mass worker'13 began to lose ground in large-scale industrial conflicts after 1973, Autonomia became more involved in the conflicts of the 'socialised worker'14 in the new post-Fordist 'diffused factory': the decentralisation of the industrial economy into a network of medium and small factories, including 'black economy' sweatshops ('lavoro nero') and the exploitation of family work, which permitted the creation of a non-unionised, flexible and 'intelligent' work force. The increasingly bitter struggle of the autonomous workers with the PCI and its associated CGIL trade union confederation led to the disintegration of working class solidarity within the factories and the expulsion by management and unions of autonomist activists. ${ }^{15}$ Political repression combined with the growing tensions caused by postFordist automation, the decentralisation of production and its resultant mass redundancies, culminating in the debacle of the 'March of the 40,000' pro-management workers and the defeat of the October 1980 FIAT strike-the event signifying the end of the post-1968 'long wave' of political and social upheaval.

Colin Crouch and Alessandro Pizzorno state that the regaining of union control over the most combative sectors (metal and chemical workers) after 1972 and the effects of economic crisis and industrial restructuring transformed the unions into organs of political control, so incorporating the base structures of representation created by the 1970 Workers' Charter into their organisational structure. ${ }^{16}$ Thus, in their opinion, the autonomous workers were effectively an unwitting motor for the expansion of trade union control over industrial conflict, the modernisation of industrial relations and the integration of the unions into the mechanisms of political consensus and economic regulation.

While partially agreeing with Melucci's observation that the historical workers movement was no longer the central antagonist of capitalism by the 1960s, Autonomist Marxism counters the argument that the new social movements represent the end of class-based conflict and politics by positing the locus of the 'social factory' populated by the 'socialised worker':

[T] he 'factory' where the working class worked was the society as a whole, a social factory. The working class had to be redefined to include nonfactory workers ... students, women and the unemployed in Italy, but also similar struggles elsewhere in Europe and the United States as well as those of peasants in the Third World. ${ }^{17}$

The autonomous workers movement, despite its clear links with the historical organisations of the industrial working class, needs to be seen, therefore, as a new social movement in that it organised among the most marginalised sectors of the industrial working class, including south Italian migrants, women and younger workers, who were in contact with and were culturally far closer to the students, feminists and counter-cultural youth of the new social movements, than the more 'guaranteed' unionised workers. While the autonomous workers movement remained mass worker-based until its demise in 1980, it also contained non-industrial and unwaged workers 
and, increasingly, the 'socialised worker' of the post-Fordist hinterland, as 'Workers' Autonomy' became Autonomia.

Marx emphasised the alienation of waged labour from the labourer, causing the worker to become relatively poorer (both morally and economically) the more wealth he produces, and that work does not only produce goods but also the worker himself as an objectified merchandise.18 The alienation of work was increasingly seen as the removal of time and opportunities to live a full life, particularly by the 1977 Movement, rather than simply the exploitation of industrial labour. ${ }^{19}$ Michel Foucault conceived the formation of modernity as a disciplinary system that made 'time for life' available to salaried work, but at the expense of every material quality. Gilles Deleuze and Félix Guattari also recognised capitalism as a system for the expropriation of human time. Thus, capitalist work was understood by that part of Autonomia closest to the 1977 Movement and the 'marginality' of mass youth unemployment as more the anthropological expropriation of 'time for life' than the economic alienation of the worker from her product. ${ }^{20}$

The autonomous workers' struggle for equality in pay and conditions for blue- and whitecollar workers, for 'less work and more money', for the democratisation of labour relations and the unions, and against technological restructuring, union bureaucracy, the post-Fordist 'diffused factory', the labour 'black market' and, above all, capitalist work as alienated activity helped to change the nature of the Italian workplace and its institutions. Undoubtedly, its revolutionary project of autonomous worker control over production was defeated by the effects of the postFordist transformation of the economy and the reimposition of union hegemony in place of workers' autonomy as a result of political repression and the 'historic compromise's' politics of austerity. What has been its legacy for contemporary Italian industrial and social relations? Can it be considered a new social movement or was it simply the extremist wing of the last stand of the industrial mass working class, the oldest social movement?

The autonomous workers movement should be regarded as a new social movement for its organisational practice, its social composition and, above all, for its radical break with the traditional beliefs of the historical workers movement and classical socialism. The movement was composed of a mixture of mainly young 'socialised workers' in the 'diffused factory' and older, often southern immigrant, 'mass workers' in the large factories. This mixture of social and cultural compositions would have made an attempted national trade union structure out of the question. Thus, the movement's organisational model of localised factory committees and assemblies-with some participation in the Factory Councils, but with no more than city-wide coordination and a minimal national coordination network-made it similar to the 'localised network' model of the new social movements. The strength of this model was to make it far more receptive to the needs of workers and changes in the workplace than the union bureaucracies, while minimising links with the hierarchical and nationally organised New Left groups. However, the lack of a national co-coordinating capacity comparable to the unions ultimately left it vulnerable to repression and 
in an isolated, minoritarian position. After 1973 and the switch of emphasis in the struggle against the 'diffused factory', its social composition became almost identical with that of Autonomia, most of whose militants were involved in workplace struggles as well as those for 'social appropriation'. However, for the antagonist youth of Autonomia and the 1977 Movement, being a 'worker', once the essence of proletarian identity, was more a condition to be avoided and certainly secondary to the counter-cultural and feminist influences on identity formation. Conversely, particularly among the older 'mass workers' and those allied with the neo-Leninist position of Organized Autonomy, the workerist ideals of 'workers' centrality' and the primacy of the struggle at the point of production remained deep-felt and this part of the movement remained ideologically aligned with the central beliefs, if not practices, of the historical workers' movement.

—FORMS OF POLITICAL ORGANISATION AND VIOLENCE: 'ORGANISED', 'DIFFUSED' AND 'ARMED' AUTONOMIA

The 'war machine' that the prosecutors pointed to was in fact a 'tank' that left pieces all over the place. [Organised Autonomia] was a reality in which party discipline was unknown. We amused the judges with our account of this 'tank' that continually broke down, infuriating the public prosecutor who was desperate to prove that this 'tank' did in fact exist. As it should have done, let's be frank.

\section{Ferruccio Dendena ${ }^{21}$}

Working class autonomy and self-organisation imply a rejection of the historical organisational forms of the class, namely the political party and the trade union, considered to be bureaucratic, centralised and hierarchical instruments of mediation and control rather than vehicles of struggle against capital. Following the FIAT occupation in March 1973 and the disintegration of the New Left groups, the question of organisation was at the centre of an inconclusive debate, first within Potere Operaio (Workers' Power) and then Autonomia. Was the loose network of localised collectives and committees that identified with the project of Workers' Autonomy to become centralised as a national party, while avoiding the sectarianism and bureaucratism of the New Left parties, so as to effectively challenge the PCI for working class hegemony and eventually state power? Or was it to remain part of the broader 'Movement' of autonomous workers, women, students and urban youth, to radicalise them still further and so transform society from the grassroots, obviating the need to 'seize power' in order to transcend capitalism?

The crisis of the New Left 'vanguard party' model, as adopted by both Potere Operaio and Lotta Continua (Continuous Struggle), led to the emergence of the 'area of Autonomia' after 1973. Within Potere Operaio a critique developed of the 'vanguard party' model. Both Potere Operaio and especially Lotta Continua's demise was conditioned by the feminist movement's influence on their women members and their consequent desire to self-organise autonomously. Within the 
'area of social Autonomia' two organisational tendencies developed: the 'movementists' and 'Organized Autonomia', accentuating the diversity of the movement, but also its disarticulation as a coherent, homogenous political force. Both attempted to break from the New Left's ideological basis for organisation by creating structures adapted to the local conditions of class composition and forms of struggle.

A third form, 'armed Autonomia', emerged after 1976, opposing the hermetically cellular 'armed party' model of the Red Brigades (Brigate Rosse) and Front Line (Prima Linea) with the semi-clandestine 'parallel structure'. Even before the collapse of the 1977 Movement, the intensification of neo-fascist violence and the criminalisation of the antagonist movements after the 'Moro Affair', 22 a section of Autonomia had begun to reorganise itself into 'parallel structures', part legal political organization, part semi-clandestine armed group. However, the failure of 'armed Autonomia's attempt to practice a form of mass armed struggle led some to leave and join the formerly decried 'armed parties', on the grounds they were the only effective forms of resistance to state repression after 1978. Since its inception, Autonomia had practiced various forms of political violence, including the use of 'molotov cocktails' during riots, 'armed marches' during the 1977 Movement and anti-fascist 'proletarian patrols' (ronde proletare). Nonetheless, many autonomist intellectuals criticised the Red Brigades in particular as anachronistic, statist and counter-productive, although widespread sympathy with and ambiguity towards the 'armed parties' also existed within Autonomia and the broader 'Movement'. ${ }^{23}$

Organised Workers' Autonomy had differing organisational modes and social compositions in the Veneto region, Rome and Milan, showing that it too was far more a heterogeneous entity rather than a uniform structure. The arrest of most of its intelligentsia on 7 April 1979 on terrorism charges marked the launch of the full-scale repression and criminalisation of Autonomia, along with most of the new social movements and political organisations to the left of the PCI. The repressive and marginalising roles of the PCI, the judiciary and the media, the experience of mass incarceration in the 'special prisons', the effects of laws permitting reductions in sentences in return for 'repentance' or 'disassociation', the exile of over two hundred of Autonomia's most active intellectuals and militants, and the demobilisation of the new social movements and their withdrawal into private life (a phenomenon described in Italian as riflusso) were all important factors in Autonomia's relatively rapid disintegration as a mass movement after 1979.

Autonomia emerged as a loosely coordinated network of localised collectives from the remnants of the New Left 'vanguard parties', whose organisational model was essentially in continuity with the Old Left. Within the broader 'area of autonomy', Organised Workers Autonomy, in its different regional forms, unsuccessfully attempted to reconstruct itself as a political party. 'Armed Autonomia' attempted to practice a semi-clandestine form of mass armed struggle, based on 'parallel structures' as an attempt to create a 'counter power' to the state, 
rather than as an insurrectional strategy for the conquest of state power as practised by the 'armed parties'. However, the logics of clandestine military organisation and state repression ultimately forced the literally hundreds of 'armed Autonomia' and 'second wave' groups into adopting the same clandestine structures and modus operandi as the 'armed parties'. In addition, parts of Organised Workers Autonomy attempted to reorganise along semi-clandestine lines, but were thwarted by the difficulties of combining open political activity with illegal clandestine violence. The state's attempt to equate Autonomia with the Red Brigades in particular and terrorism in general-the Calogero Theorem-may have been a crudely cynical manoeuvre. However, it served the purpose of mobilising public opinion through the press to support, at least passively, emergency measures of a dubious constitutional nature, initially used more against Autonomia and other antagonistic social movements than the terrorist groups themselves. In such a political climate of fear, repression and the effective suspension of basic human and civil rights, Autonomia rapidly dissolved, although a small core of collectives remained active, particularly in Rome and Padua.

In March 1977, the peak of the 1977 Movement, Autonomia was visibly the main political force to the left of the PCI, the remnants of the New Left groups either still operating in a dislocated fashion or present as individual activists (cani sciolti) within the 1977 Movement, contesting Organised Workers Autonomy's attempt to hegemonise it. Autonomia at its peak had a widespread network of local publications and radio stations and was capable of mobilising well over 100,000 militants and sympathisers for major national demonstrations, such as the banned May Day march in Milan. However, its hubris was to be brief and, as a movement, it became the victim of its own organisational success, sliding into today's ghettoised 'antagonist movement' via repression and demobilisation.

Autonomia successfully disputed the New Left groups' institutional strategy of promoting the 'government of the lefts'. ${ }^{24}$ However, it did not develop a sufficient critique of the New Left organisational model, its style of militancy, or of the internal social relations of the collective movements, thus failing to break completely with New Left praxis and its verticism, centralism, bureaucratism and male chauvinism. ${ }^{25}$ Thus Autonomia, organisationally and ideologically, represented more an attempted than a real rupture from the continuities of the Old and New Left. The rupture, instead, was to come from the 1977 Movement, with which Autonomia was the only post-New Left movement able to interact, if in a highly problematic manner.

In conclusion, Autonomia's attempt to organise the social conflicts expressed by a new generation of actors contained an unresolved tension between the 'movementist' desire to accentuate the autonomy of these conflicts through a decentralised, horizontal network, based on collective consensual decision making at the local level, and the 'organised tendency's aim of harnessing these conflicts into a revolutionary force through a revised version of the party form, based on 'parallel structures'. The contradictions between these two models led to, on one hand, 
the diffused form of armed struggle practised by 'armed Autonomia', which ultimately only provided fresh recruits for the 'armed parties', and, on the other, an internally divided movement, which was vulnerable to criminalisation and repression. From a new social movement theory perspective, Autonomia's organisational experiments represented the pouring of the new wine of the most 'marginalised' new social movements into the old bottle of a revised version of an essentially residual organisational form, the Marxist revolutionary party. For orthodox Marxists, Autonomia's rejection of 'democratic centralism' and the historical party form, and its endeavour to organise 'marginal' sections of the working class as a movement, not in subordinated alliance with the organised labour movement but in opposition, made it at best 'adventurist' and at worst 'reactionary'. From an autonomist Marxist perspective, however, Autonomia represented the first massified attempt in Italy to break from the Old, New and 'Armed' Left's ideological and organisational method of the 'party form', in order to organise autonomously the emerging 'socialised worker's struggles against work and for the direct appropriation of social and cultural needs. In that sense, it greatly influenced the future organisational forms of the Italian and European 'antagonist social movements' at the turn of the new century.

-YOUTH COUNTER-CULTURES AND ANTAGONIST COMMUNICATION: 'CREATIVE AUTONOMIA' AND THE 1977 MOVEMENT

Bologna was the happiest moment of this broader Autonomia, ... it [was] the only town where there was not a strong Red Brigades presence ... Instead [social Autonomia] was prominent culturally and intellectually. It had a sort of leadership ... also in the physical battle, but not in terrorism. The broader church of Autonomia worked very well in Bologna, so much so that [Organised Autonomia] was rather marginalised ... I disliked [Organised Autonomia] intensely then, as I intensely disliked the Red Brigades ... because I thought there was a plan, a utopia that they were putting over our shoulder, that we were their donkeys.

\section{Enrico Palandri26}

In the cycle of political and social conflict between 1973 and 1980-the parabola of Autonomia from birth to growth to suppression-1977 was undoubtedly the strategic year. The mass movement that emerged during the spring-an aggregation of students, unemployed and countercultural youth, radical feminists, gays, lesbians, ecologists and cani sciolti, Autonomia and the remnants of the New Left-was collectively categorised as the 'second society'.27 The countercultural and anti-political components that had been prominent in the 1968 movements returned to the fore, challenging the neo-Leninist and 'operaist' premises of Autonomia and the New Left through the ironic communicative action of the 'metropolitan Indians' and the linguistic 'transversalism' of 'creative Autonomia'. However, unlike 1968 there was no workers' movement in tandem or potential allies in the institutional left. The rupture with the political institutions was 
complete, the stakes were raised to their highest point and only one side could emerge intact from such an uncompromising confrontation. Whereas 1968 saw an explosion of antagonist movements, behaviours and mentalities that spread throughout Italian society, synchronising with a profound process of global social, economic and cultural crisis and change, the 1977 Movement, as the culmination of that process in Italy, represented finally an implosion of that tendency and its dispersion throughout society in an individualised rather than a collective form. The outburst of political, social and cultural innovation and creativity represented in and by the 1977 Movement ultimately fell into a void of repression and terrorism, its actors unable to maintain the tremendous momentum of February and March. The issues that had dominated Autonomia's agenda since 1973-the refusal of work, new organisational forms, anti-fascism, armed struggle and the construction of a territorial counter power-were absorbed and transcended in a matter of weeks. Autonomia, as the only remaining post-New Left mass entity, was the only overtly political movement with a space and a voice within the 1977 Movement. However, Organised Workers Autonomy's attempts to hegemonise the movement and to 'raise the level of conflict' with the state were the object of permanent contestation, whose divisive effects contributed to the movement's crisis and premature demise. While post-Marxist sociological accounts have emphasised the 1977 Movement's violent, self-destructive aspects and minimised its long-term importance, ${ }^{28}$ more sympathetic views have stressed its innovatory contribution to the evolution of contemporary Italian and European society. ${ }^{29}$

From a new social movement theory perspective, 1977 represented the grafting of the new identity-based demands of youth onto problems created by the economic crisis, particularly the disequilibria between the graduate supply and labour market demand. ${ }^{30}$ Youth and graduate unemployment had become a major social problem, emphasising the 'parking lot' role of universities. ${ }^{31}$ The movement seemed split between a quest for personal creativity and freedom, on one hand, and the protest against austerity measures and rationalisation, on the other. It was characterised by the students' awareness of their own social marginality and imminent unemployment. It also contained a strong anti-nuclear movement, whose success can be judged by the fact that today, in 2005, there are still no nuclear reactors in Italy. ${ }^{32}$ It evoked a strongly repressive reaction from the state, with violent police action against large demonstrations, and forcible evictions from squatted youth centres and university occupations. Crude measures, such as the banning of all public demonstrations for three months, the killing of a student by the Carabinieri (paramilitary police force) and the use of tanks in Bologna, and the slaying of a feminist pacifist by plain clothes police disguised as autonomists in Rome led to the degeneration of collective action into violence and encouraged, according to Melucci, the hegemony of the 'most extremist groups'.33

Evaluating the significance of the 1977 Movement and within it of 'creative Autonomia', it can be said this was more cultural and social than political. Its social composition-the 'socialised 
worker of the diffused social factory' from an autonomist Marxist perspective; unemployed intellectuals and the marginalised youth of the urban periphery from a sociological viewpointwas anticipatory of similar, but less politically radical movements in the 1980s and 1990s, particularly the 'centri sociali'. The 1977 Movement represented the re-vitalisation of the subversive side of the 1960s counter-culture, but in an inhospitable environment of increasing conformism in official culture, mass unemployment and the closure of space for collective action by state repression and the terrorism of the extreme left and right. Although youth issues, such as the creation of social spaces alternative to the family and work, access to cultural needs and the struggle against mass heroin addiction, were represented in the 1977 Movement, they have remained largely unresolved. ${ }^{34}$ In fact, the 1977 Movement had more success in campaigning around more immediate environmental issues, particularly against nuclear power, anticipating the emergence of the 1980s' 'green' movement. Although the movement developed localised communicative networks based on alternative radio and periodical journalism, and was characterised by its remarkable linguistic innovation, which allowed it to constantly bewilder and wrong foot its political enemies, it was unable to prevent its political isolation.

The movement's relations with Autonomia were problematic and Organised Workers Autonomy's attempt to hegemonise its strategic direction led to constant friction with the feminists, 'creative Autonomia' and the remnants of the New Left groups. Organised Workers Autonomy's objective of 'raising the level of conflict' with the state to take full advantage of the level of mobilisation and the economic and political crises was directly aimed at forcing the PCI to abandon its 'historical compromise' with the Christian Democrats. However, its revolutionary political agenda based on violent direct action clashed with the feminists and 'creative Autonomia's rejection of politics and the ex-New Left's aim of involving the grassroots of the PCI and unions who were dissatisfied with the 'historic compromise'. These four tendencies within 1977 were increasingly divided by the effects of repression, and the attempt to reunite them and revive the overall movement at the Bologna convention in September failed, as neither Organised Workers Autonomy nor the 'Group of $11^{\prime 35}$ were prepared to reach a compromise position, the feminists were increasingly involved in creating alternative social services and the 'creatives' had already decided to abandon the political terrain. Thus, the movement's long-term significance has come to be seen as primarily socio-cultural, with its dominant characteristics of counter-cultural and linguistic innovation, particularly in communicational forms.

The 1977 Movement itself represented the emergence of a 'metropolitan culture' with its attendant 'new individualism' ${ }^{36}$ Italian youth subcultures effectively merged with similar currents in Western societies, indeed inspiring new versions of antagonist youth cultures and forms of political action in supposedly more 'advanced' countries in the following decades. However, it also represented the definitive decline of the 'revolutionary Marxist' form of political action, based on collective solidarity, unity and ideology, only heightened by the slide of a significant section of that 
political tradition into terrorism in the late 1970s. Hence, the movement has been defined as a 'post-political' and even 'anti-communist' movement. ${ }^{37}$ However, despite its rejection of many of the premises of the historic communist movement (including the Old and New Lefts and much of 'Organised Autonomia') and its violent relations with the PCI (which it considered Stalinist rather than 'communist'), ideologically it regarded itself (including the 'creatives') as a 'communist' and certainly 'anti-capitalist' movement. It threw open the whole question of what is communism and how capitalist social relations were to be transformed, rejecting any notion of 'taking power', indeed of 'power' itself. It anticipated the hedonistic individualism of the 1980s, the collapse of social solidarity and a strongly defined 'working class' collective identity. Despite the seismic changes induced by and since the fall of the Berlin Wall, its questions on the nature of the transition to a post-capitalist society remain unanswered.

—CONCLUSIONS: THE AMBIGUITY OF REFUSAL

So, we have to premise that this word, 'autonomy', is at the same time a very complex word but also highly ambiguous. What is important is not to create through this ambiguity some major contradictions. Keeping in mind that in fact that the thought of Organized Autonomy, in particular that of Toni Negri, is a system of thought which in a certain sense has theorized ambiguity.

Sergio Bologna 38

Autonomy is rich but also a big doubt because one doesn't know if autonomy will prevail. That depends on responsibility, on individual activity and it depends on militancy.

\section{Antonio Negri 39}

The relatively brief experience of Autonomia in 1970s' Italy embodied the ambiguity of revolutionary action in the post-industrial, post-modern era. The refusal of work was to be the means by which the working class liberated its 'time for life' from the shackles of capitalism. The failure of the Autonomous Workers Movement and the radical base of the unions, however, to gain control of the technological restructuration process instead of leading to 'working less so that everyone can have a job'40 resulted in 'fewer working far more' and under the precarious conditions of the casualised, flexibilised post-Fordist organisation of labour. The refusal of the party form was the logical consequence of the spread of the autonomous self-organisation of social conflict from the factory to the 'social factory', the working class urban communities, the universities and secondary schools, the hospitals, offices, prisons and barracks. But did the decentralised horizontal network of localised collectives fully replace the statist pretensions of the neo-Leninist 'vanguard party'? Even if it did, was this not simply the substitution of the tyranny of the vertical structure with that of unaccountable structurelessness, visible hierarchy 
with invisible cliquism? These issues remain unresolved and the search for an organisational model that is both participatively democratic and structurally transparent continues.

The refusal of clandestinity was part of the dividing line between Autonomia and the terrorist formations to which the organisation and practice of violence could not be delegated, in the same way that workplace and social struggles could not be delegated to the trade union or the political party. ${ }^{41}$ Yet the very variety of positions within Autonomia and the 1977 Movement over the use of political violence, ranging from the non-violence of many but by no means all of the feminists and 'creatives' to Organised Workers Autonomy's militarism, and its ambiguity towards the actions of the Red Brigades, laid it open to unfounded accusations of being fellow travellers if not active terrorists, so hastening its criminalisation and repression. The attempt to extend the use of political violence through the use of the 'parallel structure' instead of heightening the movement's self-defensive capability led to its fragmentation as the different 'armed Autonomia' groups were forced to separate from the movement and disappear into clandestinity, some later merging with the once much criticised Red Brigades.

The 'refusal of politics' was the expression of the alienation of counter-cultural youth and much of feminism with the at times dryness and macho self-importance of the 'revolutionary Marxist' politics of the New Left and Organised Workers Autonomy. It was also an experiment in discovering a new language of antagonism, more suited to the playful needs of the generation of 1977 than the dense jargon of Marxist discourse, and a new means of communication through the 'transversalism' of the 'free radio station'. But this 'impolitic' refusal of the stolid traditions of the revolutionary left quickly disintegrated into the desperate search for individual solutions to the crisis of the movements, some through heroin addiction or neo-mysticism, some through 'repentance' or 'disassociation', some tragically through suicide, most through the return to the 'normality' of private life and the psychological 'self-removal'42 of their transgressive past. Combined with their innovatory skills in the linguistic and communicational fields and chastened by their recent experience of repression, their 'new individualism' also found an outlet in the mediatisation of Italian society in the 1980s and the rise of Bettino Craxi, Silvio Berlusconi, Umberto Bossi, the 'new social right' 43 and neo-liberalism. ${ }^{44}$

Nevertheless, despite the ambiguities of its legacy, Autonomia's relevance to the development of Italian, European and global social movements in the late twentieth and early twenty-first centuries is clear. In attempting to transcend the teleological basis of both the old and New Lefts by opposing the power of the capitalist state while refusing to seek power either within it or by capturing its apparatus, Autonomia presaged the need for a new politics of protest and revolution beyond the boundaries of both the nation-state and the continental block. In particular, many of the 300,000 global anti-capitalist demonstrators who protested against the G8 Summit in Genoa in July 2001 could trace their political roots to Autonomia, particularly the 'Disobedenti', the 'centri sociali' and the COBAS, and to a certain extent the north European 'Autonomen' (the 
backbone of the demonised 'Black Block'), even, arguably, Reclaim the Streets. ${ }^{45}$ However, whereas violence was an accepted part of social conflict in the 1970s, it is now rejected by the vast majority of Italian and global social movement participants, partly because of the bitter and stillunconcluded chapters of the past. Despite the killing of Carlo Giuliani, the first during a demonstration in Italy since that of Giorgiana Masi in May 1977, the terrible beatings given to sleeping demonstrators at the Diaz school, and the brutal repression and torture to which the authorities subjected demonstrators, Genoa was a significant step forward by the vulnerable, divided, but growing 'movement of movements'. It has marked the return of widespread international interest in the history and theory of Italian political and social movements, including the tumultuous experience of Autonomia. Autonomism - the most recent term for the version of Western neo-Marxism rooted in the practice of the twentieth-century Council Communist uprisings, French and US-dissident Trotskyism, above all in the extraordinary experience of Italian workerism and Autonomia, and now transformed by the innovative post-workerist thought of Negri, Michael Hardt, Paolo Virno, Maurizio Lazzarato, Giorgio Agamben and others-is now a rising force, part of the processes of cultural and ideological cross-fertilisation within the global anti-capitalist movements, constantly challenging the state-centredness and verticist orthodoxy of the as-yet dominant and still fundamentally Old Left - New Left factions within the World and European Social Forums.

Patrick Cuninghame completed a PhD thesis on Autonomia at Middlesex University, London, and now lectures in sociology at the Universidad Autónoma Ciudad Juárez in Mexico. <pcuninghame@postmaster.co.uk>

\footnotetext{
-NOTES

1 'Autonomia é la capacitá di darsi una regola adeguata al desiderio, e non l'arte di tenere il broncio al mondo.' Settantasette [discontinued], <http://www.taonet.it/77web.htm>. (All translations from Italian and Spanish into English are mine unless otherwise indicated.)

2 Fernando Del Corro, 'Toni Negri y un mundo desmesurado que se quedo sin teoría del valor' [interview], Autonomia Social, 2004, <http://usuarios.lycos.es/pete_baumann/Reportaje\%20del\%20Corro.htm>.

3 Mario Tronti, 'Workers and Capital', Telos, vol. 14, winter 1972, pp. 25-62; Harry Cleaver, 'The Inversion of Class Perspective in Marxian Theory: From Valorization to Self-valorization,' in Werner Bonefeld, Richard Gunn and Kosmas Psychopedis (eds), Essays in Open Marxism, Pluto Press, London, 1991, pp. 106-44.

${ }^{4}$ Interview in Italian with Ferruccio Dendena, Garbaniate Milanese, August 1998.

5 Figures taken from Nanni Balestrini and Primo Moroni, L'Orda d'Oro: 1968-1977. La Grande Ondata Rivoluzionaria e Creativa, Politica ed Esistenziale, Feltrinelli, Milan, 1997 [1988], p. 14. Of the 15,000 incarcerated (often for up to the legally stipulated maximum of five years and four months of remand before standing trial) after 1979, 6,000 were
} 
sentenced. 40,000 political arrests took place approximately between 1968 and 1982; 'almost South American data', as one informant commented.

6 Ruggiero, Vincenzo, 'Sentenced to Normality: The Italian Political Refugees in Paris', Crime, Law and Social Change Vol. 19, 1993, pp. 33-50; Oreste Scalzone and Paolo Persichetti, Il Nemico Inconfessabile: Sovversione Sociale, Lotta Armata e Stato di Emergenza in Italia dagli Anni Settanta a Oggi, Odradek, Rome, 1999. Scalzone, a former 1968 students movement leader, co-founder of Potere Operaio, Autonomia intellectual and organiser and now the unofficial spokesperson of the remaining Italian exile community in France, went on hunger strike in April 2005 in protest against deteriorating prison conditions and the obstructionism of the political class and media in Italy on the issue of amnesty or pardon (indulto) as a solution for the remaining political prisoners and exiles from the 1970s. ('Intervista: "Senza Cibo per l'Amnistia"', Il Manifesto, <http://orestescalzone.over-blog.com/article-281313.html>).

7 Often squatted and sometimes conceded public buildings, such as disused schools or factories, taken over by groups of youth, usually from the area antagonista (the successors of Autonomia) or anarchists (but also extra-comunitari immigrants and even football fans) to use as meeting places and centres of cultural, social and political activities, given the lack of the provision of such facilities by local government. A social phenomenon once unique to Italy, where squatted housing is now much rarer than in Britain, it mushroomed in the 1990s resulting in over one hundred 'centri sociali occupati/autogestiti' (squatted/self-managed social centres).

8 Antonio Negri, Oreste Scalzone and Franco Piperno were founders of Potere Operaio (1968-73), the New Left 'workerist' organisation that successfully campaigned to link the 1968 student movement to the factory-based class struggle, an alliance which lasted far longer in Italy than anywhere else in Europe. On Potere Operaio's dissolution all three were to become leading intellectual activists within Organised Autonomia and were arrested on 7 April 1979, falsely accused of being the strategic leadership of the Red Brigades.

9 The Paduans and the Volsci (named after a street in Rome where they were based) were the axis around which Organised Autonomia mobilised.

10 Interview in Italian with Alisa Del Re, Padua, 2 June 1999.

11 'Consigli di fabbrica': an attempt to gather together different political positions and restore hegemony to the unions in a unitary organisational form, capable of expressing the will of the rank and file.

12 Antonio Negri, 'The Workers' Party of Mirafiori', in Working Class Autonomy and the Crisis: Italian Marxist Texts of the Theory and Practice of a Class Movement: 1964-79, Red Notes/CSE Books, London, 1979, pp. 61-5.

13 The operaio massa was an Italian 'workerist' concept describing the dominant class composition in the factories of northern Italy from the mid 1950s, constituted principally of young, unskilled and semi-skilled internal immigrant assembly line workers from southern Italy, most typically employed at FIAT’s Mirafiori plant in Turin, with a similar economic role to other immigrant workers in Europe such as the Turkish 'guest workers' in West Germany and the 'Commonwealth immigrants' in the UK.

${ }^{14}$ A category in fact first used by Marx in Grundrisse in 1858, this further development of the concept of the 'mass worker' by Negri was an attempt to theorise the new class composition of the 'diffused factory'; the product of the new social movements, industrial restructuring, 'marginalisation' and the 'refusal of work become movement'. It remains a more controversial and less well-defined social figure than the 'mass worker'. For an acute critique of this concept, see Steve Wright, Storming Heaven: Class Composition and Struggle in Italian Autonomist Marxism, Pluto Press, London, 2002.

15 Confederazione Generale Italiana del Lavoro (Italian General Confederation of Labour), the largest of the three union confederations (CGIL, CISL and UIL). While the CGIL was linked to the PCI and the PSI (Italian Socialist Party), the CISL was a Catholic organisation with links to the Christian Democrats, while the UIL mainly had relations with the centre- 
right secular parties. It is worth noting that while all these political parties disappeared or changed their names between 1989 and 1993, the union confederations continue to exist with approximately the same political alliances. ${ }^{16}$ Colin Crouch and Alessandro Pizzorno (eds), The Resurgence of Class Conflict in Western Europe since 1968, Macmillan, London, 1978; cited in Alberto Melucci, Challenging Codes: Collective Action in the Information Age, Cambridge University Press, Cambridge, 1996, p. 263.

${ }_{17}$ Harry Cleaver, Reading Capital Politically, AK Press/AntiTheses, Edinburgh/Leeds, 2000 [1979], pp. 57-8.

18 Karl Marx, 'Economic and Philosophical Manuscripts', in Early Writings, Pelican/New Left Review, London, 1975 [1932], pp. 279-400.

19 Franco Berardi ('Bifo'), Dell'Innocenza. 1977: L’Anno della Premonizione, ombre corte edizioni, Verona, 1997.

20 Berardi.

${ }^{21}$ Interview in Italian with Ferruccio Dendena, Garbaniate Milanese, August 1998.

22 'At the moment of his kidnapping on 16 March 1978, Aldo Moro, the president of the Christian Democrat Party, was negotiating with Enrico Berlinguer on possible ways of bringing the PCI more fully into government.' Antonio Negri, 'Between "Historic Compromise" and Terrorism: Reviewing the Experience of Italy in the 1970s', Le Monde Diplomatique (English ed.), September 1998, n. 8 <http://www.monde-diplomatique.fr/en/1998/09/11negri>. 23 Interview in Italian with Alisa Del Re, Padua, 2 June 1999.

24 Until their dissolution in the mid 1970s, the tri-partite 'revolutionary left' - Lotta Continua, Avanguardia Operaia and Partito della Unitá Proletaria per il Comunismo (a fragile alliance between PDUP and Il Manifesto) each with its own national daily newspaper (Lotta Continua, Il Quotidiano dei Lavoratori and Il Manifesto respectively)—dominated extra-parliamentary politics and the sphere of the movements, its objective the 'government of the lefts' (a hypothetical coalition of the PCI, the PSI and the New Left parties) to replace the weakened and discredited Christian Democrats regime, apparently in terminal crisis. By 1973 they had evolved into fully fledged national parties along historical left lines, capable of organising national demonstrations to intervene on all the major national and international issues, and with an increasingly bureaucratic and 'neo-reformist' political line, according to their critics in Autonomia.

25 R Borgogno, 'Dai Gruppi all'Autonomia', Per il Sessantotto, vol. 11, 1997, pp. 38-46.

${ }^{26}$ Interview in English with Enrico Palandri, London, June 1999.

27 Alberto Asor Rosa, Le Due Societá, Einaudi, Turin, 1977.

28 Donatella Della Porta, Movimenti Collettivi e Sistema Politico in Italia 1960-1995, Editori Laterza, Rome, 1996; Robert Lumley, States of Emergency: Cultures of Revolt in Italy from 1968 to 1978, Verso, London, 1990; Melucci. 29 Berardi; Cleaver, 2000; Marco Grispigni, Il Settantasette: Un Manuale per Capire, un Saggio per Riflettere, il Saggiatore, Milan, 1997; George Katsiaficas, The Subversion of Politics: European Autonomous Social Movements and the Decolonization of Everyday Life, Humanities Press, New Jersey, 1997; and Wright.

30 Melucci.

31 Unemployment rose from 5.4 per cent of the total workforce in 1975 to 7.7 per cent in 1979, the highest in Western Europe. Unusually for an advanced capitalist country, female unemployment in 1975 (1.2 million) was double that of men $(600,000)$, reflecting both the huge increase in the number of women in higher education and the lack of jobs for female graduates or openings in the labour market for any woman influenced by the feminist movement and keen to escape her traditional role in the family. ('La Societá pre-77', Settantasette [discontinued],

<http://www.taonet.it/77web.htm>).

32 Robin Pomeroy, 'Kyoto forces Italy to rethink nuclear ban', Independent, 4 March 2005, < http://www.climateark.org/articles/reader.asp?linkid=39674>.

33 Melucci, pp. 268-72. 
${ }^{34}$ Heroin addiction, although less visible than in the first half of the 1980s when parks and streets near high schools were littered with hypodermic syringes, is still a major social problem in Italy, now affecting most social strata, not just unemployed, 'marginalised' urban youth. According to a Milanese informant, around three hundred skilled factory workers in northern Italy died from heroin addiction or overdoses in 1997. (Interview in Italian with three informants from Milan, July 1998).

${ }^{35}$ A group of intellectuals and prominent ex-New Left activists who virulently opposed Organised Autonomia in the assemblies of the 1977 Movement. Some of the former political foes now work together in the COBAS autonomous trade union movement.

36 Grispigni.

37 Grispigni.

38 In Patrick Cuninghame, 'For an Analysis of Autonomia: An Interview with Sergio Bologna', Left History, vol. 7, no. 2, fall 2001, p. 97.

39 In Del Corro.

40 Lavorare meno per lavorare tutti, a slogan of the Autonomous Workers Movement, Autonomia and the 1977

Movement.

41 Interview with Teresa Ciaccio, Rome, November 1982, Welschen Archive,

<http://www.xs4all.nl/ welschen/archivio.html>.

42 'Rimozione'.

43 'Nuova destra sociale': the term used in Italy to describe the growth of the populist rightist movements of the Northern League, Forza Italia and the 'post-fascist' Allianza Nazionale (ex-Movimento Sociale Italiano) in the early 1990s.

44 Grispigni.

45 The 'Disobedient', formerly known as the White Overalls Movement (the 'Wombles' in Britain), now base their political action on the practice of active civil disobedience. For a monograph in English, see Nicola Montagna,

'Questioning While Walking: The Centri Sociali and the Forms of Conflict in the Globalised Societies', in Colin Barker and Mike Tyldesley (eds), Conference Papers Vol. I: Eighth International Conference on Alternative Futures and Popular Protest, Manchester Metropolitan University, Manchester, 2002, page numbers unavailable. 